\title{
Література:
}

1. Наказ Міністерства охорони здоров'я України від 13.09.2013 № 802 «Критерії оцінки фізичного розвитку дітей шкільного віку». URL: https://zakon.rada.gov.ua/laws/show/z1694-13\#Text

2. International Report «Spotlight on adolescent health and well-being: Findings from the 2017/2018 Health Behavior in School-aged Children (HBSC) survey in Europe and Canada». URL: http://www.hbsc.org/ publications/international/

DOI https://doi.org/10.30525/978-9934-26-075-9-52

\section{PSYCHOPHYSIOLOGICAL DETERMINANTS OF HUMAN LONGEVITY}

\author{
Khliestova S. S. \\ Candidate of Pedagogical Sciences, \\ Associate Professor at the Department of Medical Biology \\ National Pirogov Memorial Medical University \\ Chorna V. V. \\ Candidate of Medical Sciences, \\ Associate Professor at the Department of Disaster Medicine \\ and Military Medicine \\ National Pirogov Memorial Medical University

\section{Gumeniuk N. I.} \\ Senior Lecturer at the Department of Disaster Medicine \\ and Military Medicine \\ National Pirogov Memorial Medical University \\ Sprut O. V. \\ Assistant at the Department of Medical Biology \\ National Pirogov Memorial Medical University \\ Khliestova I. V. \\ 4th-year student of Medical Faculty № 1 \\ National Pirogov Memorial Medical University \\ Vinnytsia, Ukraine
}

The problems of aging of the human body, longevity, and death in all times of the world have always worried mankind. Aging of the body is a genetically 
determined process of individual development, which has been manifesting in the gradual damage of cells and functions of the body, which ultimately leads to their death. If the aging of the human body occurs without pathological complications caused by diseases of various etiologies, it is physiological.

The consequence of physiological aging is longevity, which is considered a socio-biological phenomenon and has characterized by the fact that a person lives to a high age, which significantly exceeds the average life expectancy. Therefore, long-lived people have considered being over 90 years old. Issues of influence on longevity growth have been covering in scientific researches of domestic and foreign scientists L. Bettendorf, A. Ditton, A. Zhavoronkov, A. Sen, D. Cutler, S. Olshansky, T. Picketty, and many others [3].

The aging process of the human body does not exist in itself as a function of the astronomical time it is the result of the work of the body, which carries out the program of development, and then transforms it into a program of aging. The regulatory processes of normal aging have been determining by causes that could have been influencing. However, the maximum duration of human life is still unknown. According to paleontological excavations, the lives of primitive people were very short because most of them died at the age of 15 . With the progress of mankind, life expectancy has begun to increase steadily and today averages more than 70 years. For example, in 2019 in Norway, Switzerland, Japan life, expectancy was over 88 years in Ukraine, it is 70.1 years [7].

The ability to longevity is genetically programmed, but the genetic potential is realized only under certain conditions of everyday life. Analyzing the causes of death in general, $85 \%$ of people die from both acquired and hereditary diseases. Most people die from autoimmune diseases, strokes, obesity, cancer, mental disorders [4], traffic accidents, and injuries of varying severity [6].

The aging of the human body begins immediately after birth. The internal processes of human aging under normal conditions become noticeable from the age of 30-35, namely: muscle strength weakens, endocrine glands, especially gonads, become dysfunctional, fundamental metabolism is significantly disturbed, and susceptibility to infectious diseases increases. Externally, the signs of aging begin to appear in gray hair and hair loss, dryness and wrinkling of the skin of hands and face, brittle bones, and more.

Not only stressful situations, mental stress, bad habits but also the hypothalamus, which over time reduces its sensitivity, play a crucial role in human aging. More and more mediators are needed to ensure its presensitivity. This is especially evident in the regulation of appetite. The feeling of satiety has been providing by the action of nutrients in the blood on special receptors of the hypothalamus [1]. But with a decrease in the sensitivity 
threshold, the feeling of satiety appears at a much higher concentration of these substances in the blood, resulting in overeating and overweight. Excess fat, in turn, restructures metabolic processes in the blood and leads to increased concentrations of insulin and somatomedin in the blood, to the use of fatty acids instead of glucose as an energy source. Excess fat has been capturing by leukocytes, so they can no longer respond to foreign agents and trigger the immune system, which increases the likelihood of contracting infectious, cancer, and diabetes.

According to the World Health Organization, human health and life expectancy depend on $60 \%$ - on lifestyle and lifestyle, $30 \%$ - on the ecological state of the environment, and $10 \%$ - on the level of development of the country's health care system [2]. The ratio of life expectancy in terms of $\%$ is showing in Figure 1.

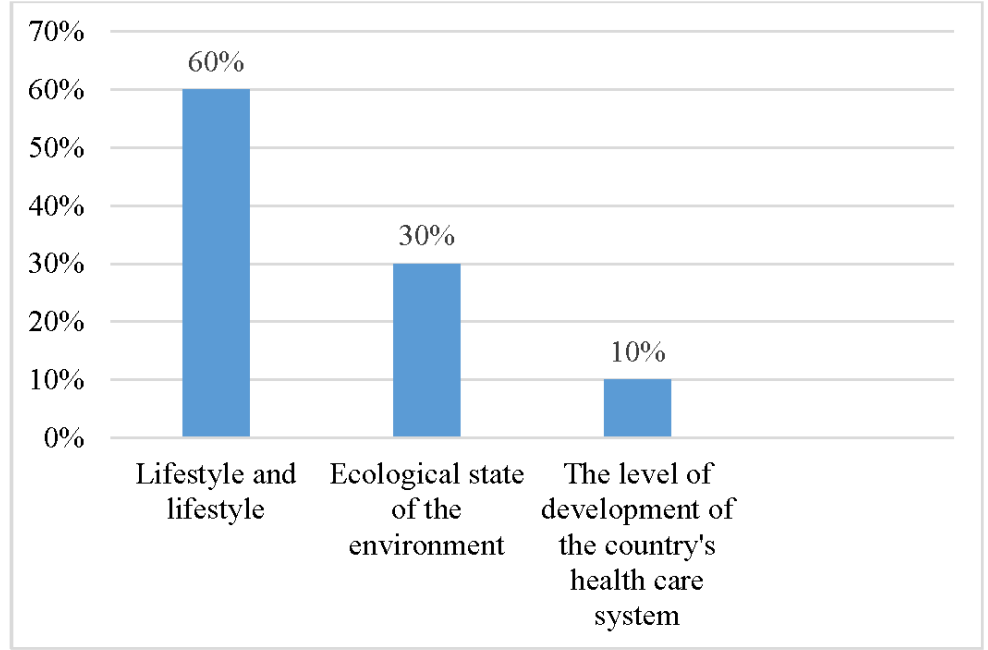

Fig. 1. The proportion of human life expectancy, \%

Indicators of mental illness, disability, life expectancy, and mortality in Ukraine have been steadily deteriorating in recent years, pointing to a deep health crisis and the need to modernize the health care system [2].

The psychophysiological determinants of growth of active human longevity should include: determinants of the health care and social protection system - access to primary, specialized, and highly specialized medical care, disease prevention, public health care, social services; behavioral determinants - tobacco use, physical activity, nutrition; determinants of the physical 204 
environment - housing, safety and sanitary and hygienic living conditions, safety and quality of food, the state of the territory; determinants of the social environment - education, the presence of family and close friends, involvement in social support networks; personal determinants - genetics, psychological factors, etc [5].

Given the above, it could have been concluding that no science has yet given a comprehensive answer to the question of the causes of human longevity, but it is reasonable to say that the origin of longevity is natural, which depends primarily on genetic factors and lifestyle.

\section{References:}

1. Боцюрко В.І., Костіцька I.О., Дідушко О.М., Марусин О.В., Чернявська І.В. Дисфункція гіпоталамуса: етіологія, клініка, діагностика, лікування (методичні рекомендації). Міжнародний ендокринологічний журнал. 2017. № 4. Том 13. C. 290-296. DOI: https://doi.org/10.22141/22240721.13.4.2017.106659

2. Чорна В.В. Детермінація психічного здоров'я населення України та країн СС. Довкілля та здоров'я. 2020. №2(95). С. 47-53 https://doi.org/10.32402/dovkil2020.02.047

3. Дитон А. Великий побег: Здоровье, богатство и истоки неравенства. - М.: Изд-во Института Гайдара; Фонд «Либеральная Миссия», 2016. $368 \mathrm{c}$.

4. Chorna V., Makhniuk V., Gumeniuk N., Khliestova S. \& Tomashevskyi A. Comparative analysis of morbidity indicators among the population of the eu and Ukraine under conditions of stressed load of the Antinerrorist operations and psychoprophylaxis measures. Georgian medical news. 2020. № 5(302). P. 147-154.

5. Healthy ageing literature review. Final report to the Department of Health and Human Services. 2016. URL: https://www2.health.vic.gov.au/ Api/downloadmedia/\%7B33D1A7A1-08BC-4F7F-90A4-

B8B7FC2BCA72\%7D

6. Makhnyuk, V. M., Chorna, V. V., Khliestova, S. S., Gumeniuk, N. I., $\&$ Shevchuk, T. I. Prevalence of injuries among the population of the Vinnitsa city. Georgian medical news. 2020. № 1(298). P. 17-21. Retrieved from https://pubmed.ncbi.nlm.nih.gov/32141841/

7. UNDP (2019). Human Development Report 2019: Overview. Beyond income, beyond averages, beyond today: Inequalities in human development in the 21st century. New York, NY 10017 USA: United Nations Development Programme One United Nations Plaza. Retrieved from http://hdr.undp.org/ sites/default/files/hdr2019.pdf 